\title{
AIS自船局記録データの航海支援への利用可能性
}

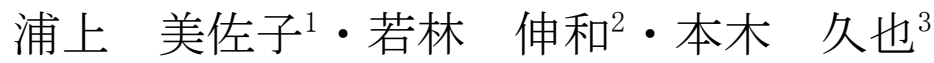

\section{Proposal of utilization of the accumulated AIS own ship data to optimal supporting for navigation system}

\author{
Misako URAKAMI, Nobukazu WAKABAYASHI and Hisaya MOTOGI
}

\begin{abstract}
We view AIS (Automatic Identification System) as a probe information system. Then, it can be said that a vessel is the probe of marine traffic. Nowadays, AIS information is mainly received and collected by each AIS land station near the coast in Japan. After that, it's provided to a vessel and maritime society by creating added value in collected information. However, the information received at the AIS vessel station is not included. That isn't probe information system in the true meaning.

In this research, the AIS information received by the AIS vessel station explored. First, the past record of the course line of T.S. FUKAE MARU explored that received by the AIS land station in Kobe University and the AIS vessel station in T.S. FUKAE MARU. In particular, the communication message is also contained in the AIS information received by the AIS vessel station. These messages were also explored. Next, we propose the probe information system using the information received by the AIS vessel station. We configure the standards of degree of attainment that the proposed probe information system supported a navigation. According to evaluation results, the proposal system lived up to certain standards.
\end{abstract}

Keywords: information support, AIS, big data of navigation, probe information system, navigation support キーワード: 情報支援，AIS, ビッグデータ，プローブ情報システム，航行支援

\section{1. はじめに}

陸上 ITS (高度道路交通システム) 分野において、 走行車両そのものをセンサとしてとらえ位置情報等 の動的情報を取得して、交通把握を行うことをプロ ーブ技術と呼ぶ(1)(2)。このプローブ技術を海の ITS (高度海上交通システム) 分野で考えると、AIS (Automatic Identification System、船舶自動識別装置) が該当すると考えられる。船舶は海上交通のプロー ブ（探查針）とみなされ、AIS 船舶局から得られる AIS 情報（船名や船種などの静的情報及び船位や対 地速力などの動的情報など）をリアルタイムな情報
として収集し、船舶や海上交通社会全体に提供する ものであると言える。既に、日本では、海上交通管 理システムや船舶会社による所有船舶の運航管理シ ステムなどで活用されている。しかし、既存システ ムでは、AIS 陸上局が主体となって情報が集められ ており、AIS 船舶局で得られる情報は、船舶間にお ける衝突回避等の操船のためにリアルタイムで使う ことのみに視点が向けられてきた。特に、沿岸から 離れた航海中は、AIS 船舶局が発信する情報を受信 できるAIS 局がないため、貴重な航海情報（プロー ブ情報）を捨てている状況であり、オンボードで蓄

\footnotetext{
1 正会員 大島商船高等専門学校情報工学科（干 742-2193 山口県大島郡周防大島町小松 1091-1） misako@oshima-k. ac.jp

2 正会員 神戸大学大学院海事科学研究科

3 正会員 大島商船高等専門学校商船学科 (大島丸一等航海士)
} 
積し活用した事例はみあたらない。これまでのよう な陸上局視点で利活用される状況では、個々の船舶 がプローブとして航海支援への活用可能性を最大限 に活かしきれていない。

プローブとなる AIS 船舶局視点（特に自船局）に 立つためには、AIS 船舶局が実際に得ている情報を 正しく知ることが重要である。本研究では、まず,

AIS 陸上局で受信した神戸大学練習船深江丸の航海 情報の調査、および、深江丸が AIS 自船局で得た航 海情報の調查を実施した。なお、日本沿岸付近を航 行中の自船局で得られる航海情報には、航海履歴だ けではなく、各海上交通センターからの安全関連情 報も含まれているため、安全関連情報についても調 查した。次に、自船局視点のプローブ情報を利用し た航海支援システムの有用性を示すために、支援達 成度基準を設定し評価をした結果、提案方式は一定 基準を満たした。今後さらなる工夫によって AIS 船 舶局をプローブとみなし、AIS を用いたプローブ情 報システムが実現可能であることについても述べる。

\section{AIS を用いたプローブ情報システム 2. 1 プローブ情報システムの概要}

プローブ情報システムには、Fig.1 に示すよう

に、自動車をセンサとして用いるプローブカーや人 間をセンサとして用いるプローブパーソンというア プローチがある。近年、陸上における ITS 分野では プローブ情報システムへの関心が高まっている。自 動車をセンサとして用いるプローブカーシステム

は、実際に走行している自動車一台一台から得られ た情報（車両位置、時刻、速度・加速度、ワイパー ON/OFF 等）を収集し、その情報価值を高めて、各 種支援コンテンツとして提供し、利用者同士が情報 共有できるシステムである (Fig.2 参照)。このシス テムは、道路に取り付けられたセンサから交通情報 を生成するVICS（道路交通情報通信システム）と 比較して、理論上、車両が走行する全道路の交通情 報を生成することが可能となる利点がある。近年で は、車両から集めた位置や速度などの膨大なプロー ブ情報であるビッグデータを基に、ビッグデータ交 通情報サービス(3) として、交通量や通行可能な道路 情報の提供による交通渋滞の回避や、急ブレーキ多 発地点の提供による危険地点の推測等を支援するサ ービスが実用化され始めている。

その一方で、各センサ（車や人など）からの情 報収集のための通信部分にコストがかかることや各

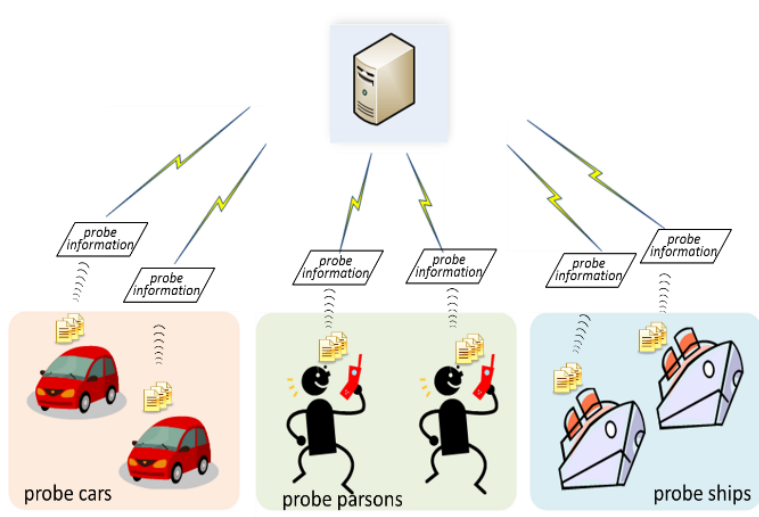

Fig. 1 Various probe information systems
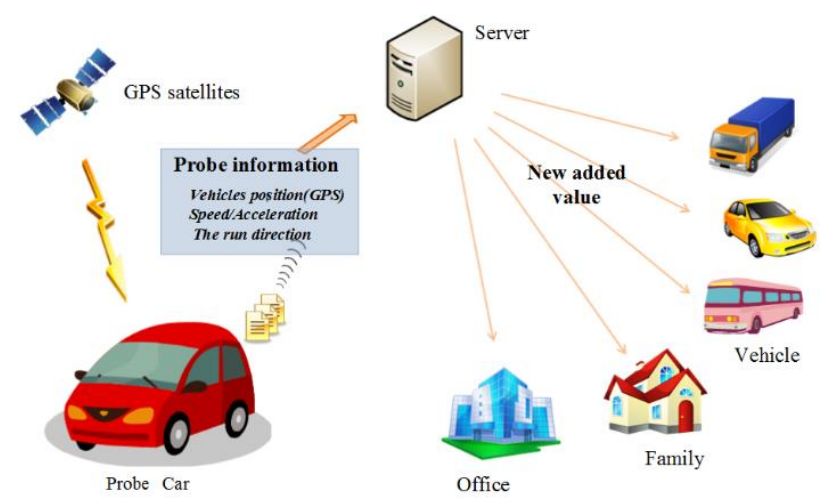

Fig. 2 Probe information systems (probe car)

センサ情報として得られる個人情報の公表や利用に ついて、個人情報保護の問題が存在する(4)。また、セ ンサの機器仕様はメーカ対応となり、全ての車や人 が搭載しているわけではないため、情報源となるセ ンサの偏りの問題も存在する。

\section{2 海上におけるプローブ情報システム}

2.1 節で示した陸上のプローブ技術を海の ITS 分 野で考えると、AIS が該当すると考えられる（Fig.1 参照)。そのとき、船舶は海上交通社会のプローブと みなすことができる。筆者らがこのように考える理 由は、(a)特定の船舶に対して AIS は搭載義務化され ていること、(b)非搭載義務船向けにも無線従事者が 不要な簡易 AIS の普及が勧められていること、(c)静 的・動的情報、航海関連情報・安全通報など主な情 報が標準化されていること、(d)情報を一定間隔で自 動的に送受信する通信機能が AIS に組夕込まれてい ること、を挙げたい。

このように AIS をプローブ情報システム（以下、 プローブシップシステムと呼ぶ）としてみたとき、 2.1 節で述べた通信部や情報源となるセンサの偏り などといった陸上 ITS におけるプローブ情報システ 


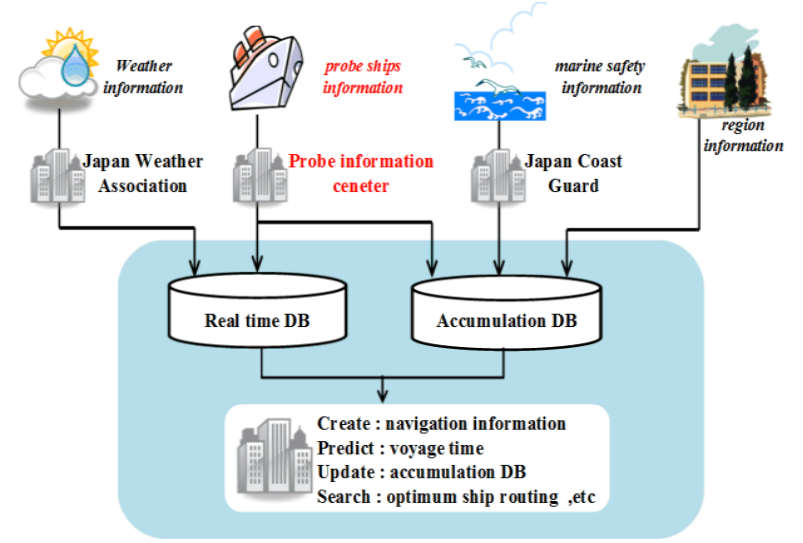

Fig. 3 Outline of the probe ship system

ムでの問題が既に解決されていると考えることがで きる。現在、プローブシップシステムは、プローブ シップから得られる情報に、日本気象協会等から得 られるリアルタイムまたは予測した海象・気象情報 や地域安全情報等と共に加工し、価值を高め、安全 対策や運航効率を目的として活用され始めている。

Fig.3 にプローブシップシステムの情報の流れを 示す。例えば、海上保安庁において航行船舶のリア ルタイムな位置把握や安全通報による海上交通行政 での活用 ${ }^{(5)}$ 、海洋台帳での交通量把握 ${ }^{(6)}$ 、輻輳海域で の事故回避のための安全システム(7)、海の ITS ${ }^{(8)}$ でも AIS が利用されている。また、海賊事件の地理的分 布特性把握のための防犯面からの解析 ${ }^{(9)}$ 、内航船の 効率的航海へのアプローチ(10)等にも利用されてい る。しかし、伝搬距離の制約で広域をカバーするた めの複数の局設置費用は高額となるため、一般利用 には負担金が発生する場合が多く、容易に利用可能 だとは言い難い。

これらは、AIS 陸上局または AIS 衛星局が受信し た情報が主である。(a)AIS はV VHF 帯の電波を用いて 情報の送受信を行うため、カバーエリアが約 30 海 里と狭いこと、(b)輻輳海域内では、AIS 受信精度は スロット久損の影響を受けるため精度に不安を持っ ていること、(c)AIS 搭載義務船クラスの船であれば、 VDR (shipbone voyage data rechorder, 航海情報記録装 置) 等航海履歴を保存する装置を備えているため受 信した AIS データをすべて記録する必要性を考えて いないこと等があり、自船の AIS 情報を自船で活用 するプローブシップシステムを検討しなかったため と考えている。

\section{3 AIS 自船局を用いたプロープシップシス テムの検討}

プローブ情報の取得スピードにより、指定した時 間ごとに情報提供するリアルタイム型プローブと利 用者が好きなときに情報提供する蓄積型といった考 え方が存在する。

AIS 自船局の AIS 情報を蓄積することは、蓄積型 プローブシップシステムであるといえる。

まず、蓄積する情報のうち、自船の航海履歴に着 目する。これまで研究目的等をのぞくと、AIS デー タをオンボードで蓄積しているものはほとんどなく、 安全航行のための操船に使うことのみに視点が向け られてきた。特に、沿岸から離れた航海中は、AIS 船 舶局が発信する情報を受信できる AIS 陸上局がない ため、貴重なプローブ情報を捨てている状況である。 なお、先に述べた VDR は船のブラックボックスと呼 ばれるが、IMO の性能基準が要求する時間は過去 12 時間分であり、長期間にわたる蓄積は考慮されてい ない。

次に、AIS 搭載船に対して海上交通センターAIS 局 から送信される安全関連情報に着目する。Fig. 4 に 示寸ように現在 4 つの安全関連情報が通報されてい る(11)。このような状況にも関わらず、あまり活用さ れていない。その理由は、操船中に AIS の小さなデ イスプレイから得られる安全関連情報を確認するの は困難であること、また、AIS 搭載前から存在する VHF 無線電話装置を使った音声やインターネット経 由の電子メールや FAX 等で気象・海象を含めた安全 関連情報を確認することで十分であることから、AIS 自船局で得られる安全関連情報に着目したシステム 開発の事例はない。

しかし、これらの安全関連情報は、船舶にとって 貴重なデジタル情報である。そのため、プローブシ ップシステムで活用方法を見出すことができれば、 免許が必要な国際 VHF を設置していなくても、安全 関連情報が自動的に得られるため、海上における情 報弱者を減少させることにも繋がると考えられる。

\section{3. 航海支援のための提案システム 3.1 提案システムの特徵}

本論文で提案する AIS 自船局が蓄積型プローブと して、自船の AIS 航海履歴を用いて航海支援情報を 提供する方式といったセルフマネンジメントを実施 する場合は、(a)AIS 自船局で取得した AIS 航海情報 は、自ら蓄積するため無料であること、(b)AIS 陸上 局や他船局からではスロット衝突の問題でデータ欠 落がある場合も考えられるが(12)、この問題は発生し 


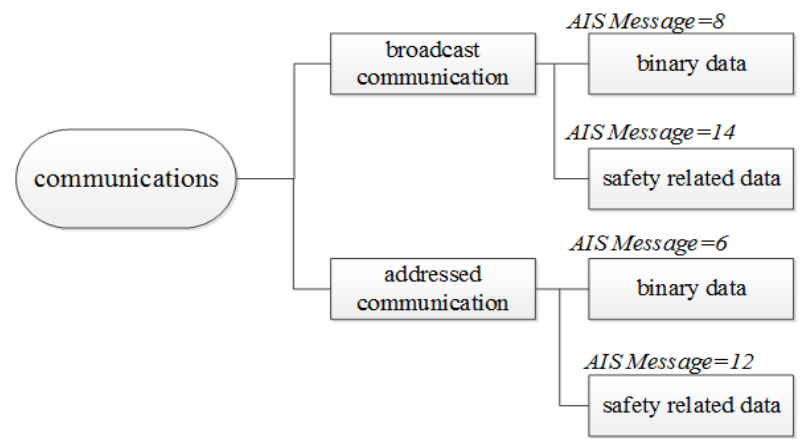

Fig. 4 Four communication messages in AIS

ないこと、(c)自船が自船の航海履歴を利用するため、 法律上の秘密の保護の問題 ${ }^{(13)}$ は発生しないこと、(d) 自船以外と情報共有する場合は、帰港後に無線 LAN 等のブロードバンド回線網に切り替えれば実現可能 であること ${ }^{(14)}$ 、といったメリットが考えられる。な お、本稿では出来る限り AIS の活用検討をしている ため、航海支援のための航行警報(15) との連携につい ては言及しない。

\section{2 提案システムの評価基準}

本稿では、AIS 自船局が送受信した AIS 航海履歴 を蓄積型プローブとして捉え、その蓄積されたプロ 一ブ情報を高度にし、航海支援情報として自船で活 用する方式を提案する。

本提案方式を実現するためには、(1)AIS 航海履歴 が欠損なく記録できること、(2)航路確定のための気 象・海象や管制信号情報等の安全関連情報が正しく 受信できること、を調査し、有用性を評価する必要 がある。したがって、本稿では、これら (1) (2)を支 援評価基準と定め、AIS 陸上局で受信した神戸大学 練習船深江丸の AIS 航海履歴の調查、および、深江 丸が自船局で記録した自船の AIS 航海履歴と受信し た安全関連情報の調査を実施した。

\section{4. 提案システム実現可能性に関する調査 4. 1 調查内容}

口調査 1 : AIS 航海履歴が久損なく記録できること まず、陸上局の調査（神戸大学海事科学部）と して、4 種類の履歴を調査した。

- 2010 年 11 月 9 日、

- 2012 年 5 月 8 日、

- 2012 年 6 月 12 日、

- 2012 年 9 月 11 日

次に、自船局の調査（深江丸）を行った。

- 2012 年 8 月 30 日〜9 月 6 日：（神戸-長崎）
調査 2 : 気象 - 海象や管制信号等の安全関連情報 が正しく受信できること

自船局の調査（深江丸）を行った。

- 2012 年 8 月 30 日〜9 月 6 日：(神戸一長崎)

- 2012 年 6 月 12 日〜 6 月 15 日：(神戸一松山)

\section{2 AIS 陸上局による AIS 航路履歴}

神戸大学海事科学部の AIS 陸上局(16)で受信した深 江丸の出航時の航路（4 種類）の位置情報（緯度経 度）を Fig.5 に示す。なお、AIS から得られるプロー ブ情報はAIS で取得できる全情報を指すことが出来 るが、便宜的にここでは位置情報とするため、位置 情報を中心点とした円で可視化した (GoogleMaps 利 用)。

可視化したことにより分かったことは、(1)データ 欠損が複数存在すること、(2)伝搬距離が観測日によ って異なるため受信（記録）範囲が異なること、(3) 気象・海象状況が同程度の場合、コースラインは若 干異なるが、変針点などはほぼ同じであることが分 かった。

\section{3 AIS 自船局による AIS 航海履歴 (航路履歴 と安全通報情報）}

Fig.6 は、深江丸が自船局で記録した自船の AIS 航 海履歴である。2012 年 8 月 30 日に阪神港神戸区 (神 戸大学深江地区）を出航し、9月 1 日に長崎入港、9 月 4 日に長崎を出港し、9 月 6 日に神戸に帰港した 際の自船 AIS の位置情報による航路図である。本船 で記録した自船 AIS 情報は、この 8 日間、1 秒間隔 ですべてのデータが記録されており、欠損は認めら れなかった。これは、送信データとして準備してい る 1 秒毎のデータを、AIS 送受信機からシリアルイ ンターフェイスを介して直接データを受け取って

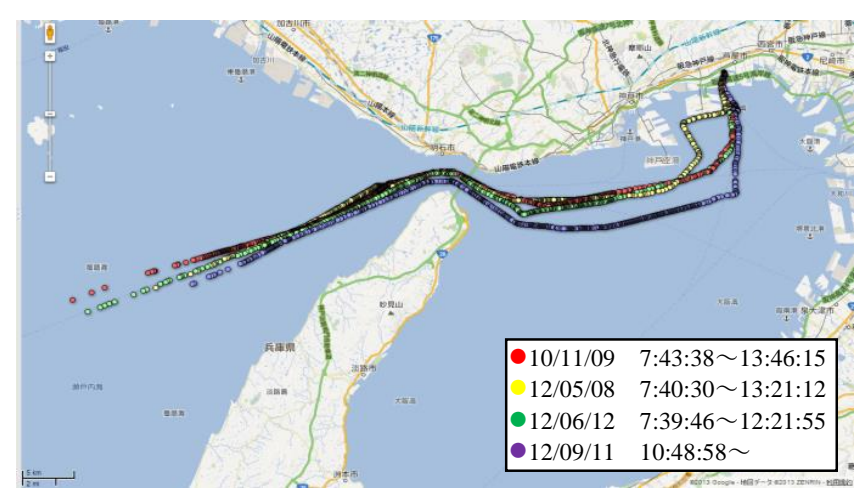

Fig. 5 past record of the course line (received by AIS land station) 


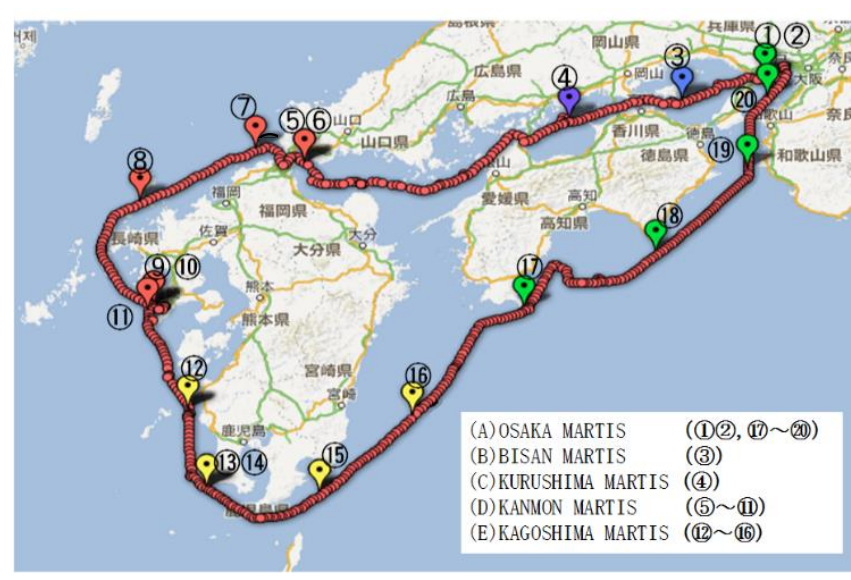

Fig. 6 AIS information received by AIS FUKAE-MARU station (past recorded of course line \& addressed communication / binary data )

PCで記録しているためである。他船や陸上局との間 のデータ交換とは異なり、途中に雑音が含まれる可 能性のある無線通信等は含まれていない。もし欠損 があれば、それは AIS 機器の問題となる。なお、実 際に AIS 送受信機から送信されるのは、航行中でも 速力等の条件により 10 秒ごとか 3.3 秒ごとまたは 2 秒ごとである。これに比べて自船の記録では 1 秒ご とのデータが得られる。

次に、通報履歴に着目する。通報は Fig.4に示すと おり MessageID 番号が決められている。Fig.6の(1)〜 (20)に、海上保安庁の AIS 陸上局から深江丸が宛先指 定バイナリ通報（Message ID：6）を受信した時の船 位を示す。本航海中に受信したメッセージは大きく 分けて三種類であった。

一つ目は、Weather Information で、20 回中 13 回 （1、（3＜wide>（8)、(15)～(20)）であった。気象、海象情報 として、風速・風向、潮流があった。なお、OSAKA MARTIS の場合、OSAKA VTS や TOMOGASHIMA からの情報発信も含まれていた。二つ目は、 Information で、20 回中 1 回（(2)）の海上交通センタ 一からの取組夕紹介情報であった。三つ目は、

Warning で、20 回中 3 回(9)〜 (11))の停泊中の警告情 報であった。具体的な情報内容の一部を Fig.7 に示 す。

そして、Fig.8～Fig10 の安全関連情報に着目する。 地図中のラインは、深江丸が航海した航路である。

MessageID 8 (一般情報放送通報）は、浅瀬等の情 報、MessageID 12 (宛先指定安全関連通報) は Warning で停泊中か座礁かの問合せ情報、MessageID 14（安 全関連放送通報）はBISAN MARTIS から管制信号情

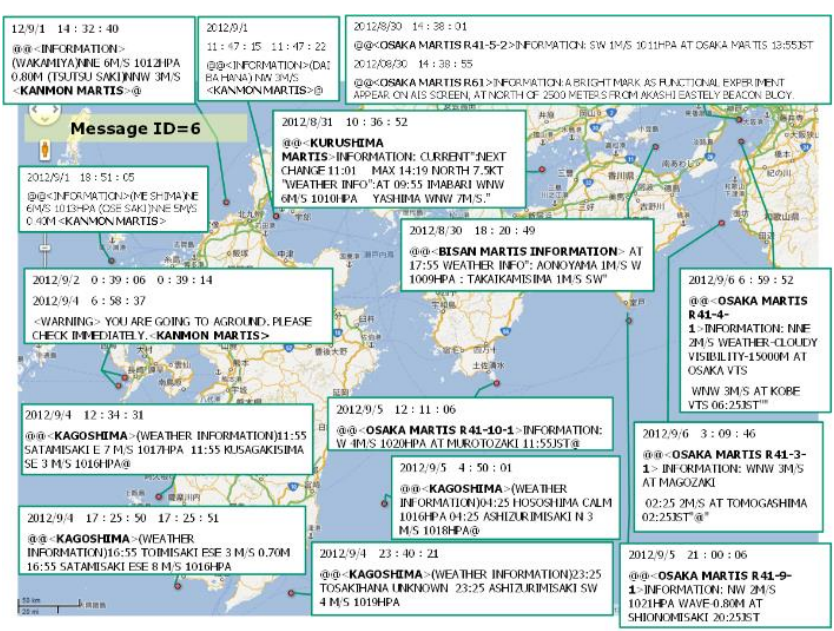

Fig. 7 message ID_6 received by FUKAE-MARU station

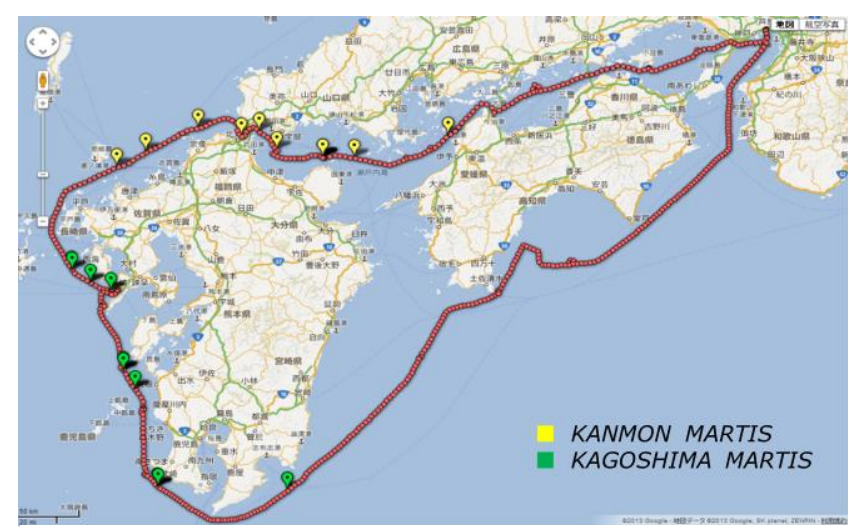

Fig. 8 message ID_8 received by FUKAE-MARU station

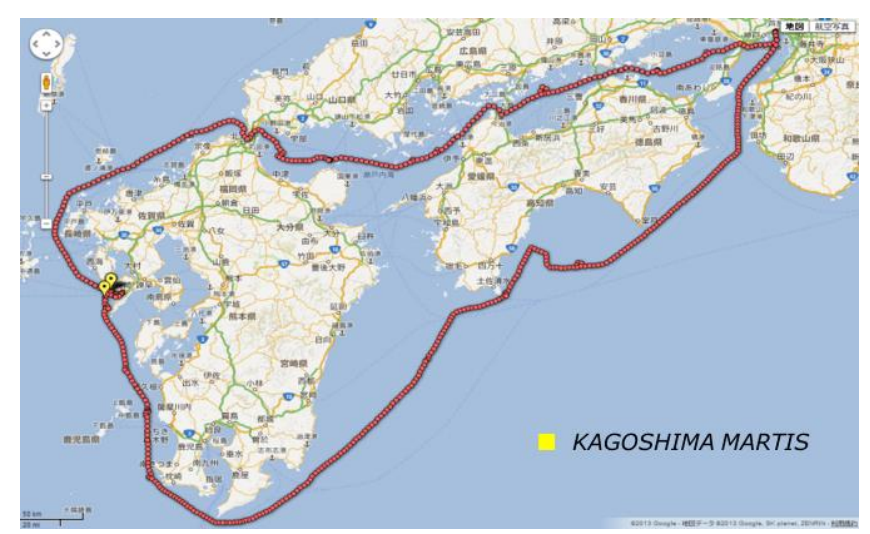

Fig. 9 messageID_12 received by FUKAE-MARU station

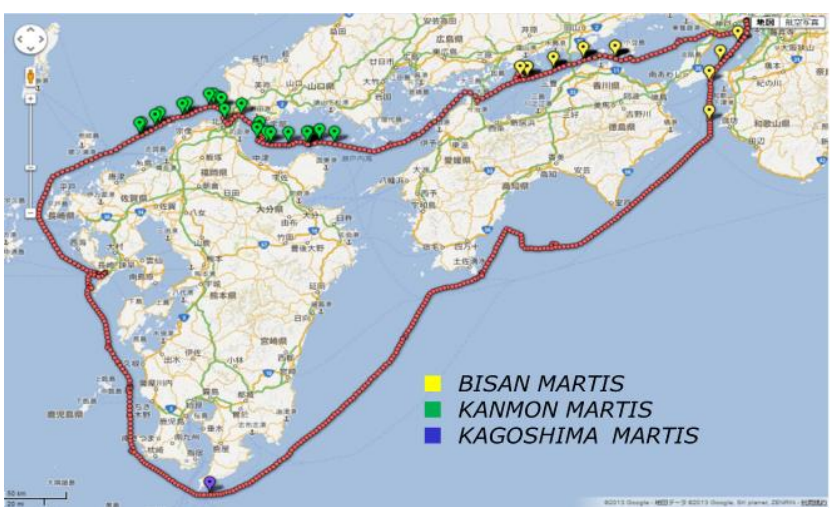

Fig. 10 message ID_14 received by FUKAE-MARU 
報と KANMON MARTIS の特定航法や追越しに関 わる注意情報があった。

このように航行中の気象・海象情報は、久損なく、 蓄積されていることがわかった。また、VHF 無線電 話では危険な情報が強調されるため、VHF 無線電話 では聞き逃してしまうような詳細情報も蓄積されて いることがわかった。しかし、安全関連情報のうち、 放送通報は本船に関係無い情報も受信してしまうた め、情報をスクリーニングする手法を検討しなけれ ばならないこともわかった。

以上の調查結果から、3 章で設定した支援達成度 基準を満たしていることを確認することができた。

\section{5. おわりに}

調查結果より、AIS 自船局で得られる自船の航海 履歴は、1 秒毎のデータとして久損なく蓄積可能で あることを確認した。そして、自船に重要な気象・ 海象や管制信号情報などの安全関連情報も正しく受 信できることを確認した。これらの結果より、本稿 で設定した航海支援達成度基準を満たしていること を確認することができた。なお、AIS 自船局で得ら れる他船の航海履歴は、船間距離の影響等により受 信率に影響を受けることがわかっている(17)。これら のことも考慮し、AIS をプローブ情報システムとし て捉え、自船の AIS 航海履歴を蓄積型プローブシッ プシステムとして高度にし、航海支援情報として活 用するシステム開発に取り組んでいきたい。

具体的には次のような航海支援を検討している。 自船の航海履歴の中から、航路を確定する変針点を 精度よく読み取ることができ、ブロードキャストで 受取る安全情報の中から自船に必要な情報のみ抜き 出すことができれば、提案システムを用いて、自船 で取得した自船の AIS 航海履歴を元に、自船の航 路履歴（変針点の取り方や気象・海象との関係）が 正しかったのか、改善点があるのか等の確認ができ る。また、蓄積された過去の AIS 航海履歴（現在 位置及び安全通報情報）を基に簡易なウェザー・ル ーティングへと発展させていくことも考えられ、航 海支援が可能となるといえる。現在、AIS の安全通 報情報は沿岸航行寸る船舶でなければ伝搬距離の問 題で受け取ることができないが、将来的に衛星 AIS が容易に利用可能となれば、全 AIS 搭載船で利用 可能となるといえる。さらに、情報共有可能な船舶 同士で航海履歴を共有することにより、船舶間でも 活用可能な支援システムへと発展させていきたい。

\section{謝辞}

東京海洋大学の庄司るり先生には、AIS 勉強会等 において貴重な意見をいただいた。AIS 情報解析を するにあたり、本校練習船大島丸藤井敬治船長（当 時)、本校商船学科久保田崇先生にご意見をいただき、 本校研究支援員の梄松かおり氏（当時）に情報整理 のご協力をいただいた。なお本研究は、科研費基盤 研究(C)(No.25420876)の助成を受けたものである。こ こに付記して謝意を表する。

\section{参考文献}

（1）プローブ情報の利活用による道路交通情報の高精 度化に関する調查検討報告書：総務省, 2009. 3.

（2）牧村和彦: プローブデータに基づく交通状況の予測, 国際交通安全学会誌，Vol.31，No. 1, pp. 31-38, 2006. 6.

（3）ビッグデータで交通情報を配信一車 330 万台分を 解析一, 日本経済新聞, 2013.5.30.

（4）原田昇・吉井稔雄・牧村和彦: プローブデータを取 り巻く動向と課題 (2005),

http://www. transport. iis. $\mathrm{u}^{-}$ tokyo. ac. jp/PDFs/2005/2005-007. pdf， 2013. 2. 10.

（5）AIS を活用した航行支援システム (海上保安庁)： http://www. kaiho. mlit. go. jp/syoukai/soshiki/t oudai/ais/ais_index.htm, 2009. 10.

（6）吉川貴子:海洋政策支援情報ツール(海洋台帳)の構 築, 平成 24 年度海上保安庁海洋情報部研究成果発 表会講演予稿集,

http://wwwl. kaiho. mlit. go. jp/GIJUTSUKOKUSAI/K ENKYU/happyo/2012/h24o02. pdf, 2013. 3. 10.

（7）海上技術安全研究所：ふくそう海域での事故半減 を目指す ICT を活用した新たな安全システムの構 築報告書, 2012.3.

（8）秋田務：21 世紀の交通技術戦略から〜海の ITS 構 想について, 日本航海学会誌Vol. 145, pp. 29-32, 2000. 9.

（9）渡川真規 - 古莊雅生 - 若林伸和 -小林英一 : 地理 情報システムを用いた海賊事件分析, 平成 24 年度 秋季講演会予稿集, http://members. jnavigation. org/doc/JIN127-1. pdf, 2013. 3. 10.

（10）高嶋恭子 : 内航商船に対するウェザー・ルーティ ングについて（東海大学海洋学部海事研究プロジ エクト研究報告第 2 号より抜粋), http://www. ymf. or. jp/wp-content/uploads/608. pdf. 2013. 3. 
(11) Recommendation ITU-R (Rediocommunication Sector of ITU) M. 1371-4, 2010. 4.

（12）山本淳・田中隆博・山田多津人：AIS (船舶自動識 別システム)を利用したVHF 伝搬の観測, 海上保安 大学校研究報告, Vol. 49 (1・2), pp. 21-32, 2005

（13）鈴木治・田中友規・浪江宏宗・藤井肇 : 海上交通 流把握のための陸上と船からのデータ収集システ ム, 日本航海学会誌, Vol. 123, pp. 111-117, 2010.9

（14）浦上美佐子・幸田三広 : 自律的無線ネットワーク による被災情報提供システム，消防防災科学技術 研究推進制度研究成果報告書 (平成20～22年度), 2011. http://genome. ib. sci. yamaguchiu. ac. jp/wlan2/xoops/

（15）田中弘之 - 阿部正志 - 平出昭夫 - 出合好美 - 長野 伸次・宮井義裕・柴田和宏・石原健一郎・木村信 介・藤澤豪・藤田雅之・山本正・土橋一夫 ・ 岡田 武男: 航行安全情報, 海上保安庁海洋情報部研究 報告第49 号, pp44-49,

http://www1. kaiho. mlit. go. jp/GIJUTSUKOKUSAI/K ENKYU/report/rhr49/rhr49-a03.pdf, 2013. 3. 10.

（16）若林伸和，塩谷茂明，小林英一，庄司るり：

“AISを用いた大阪湾海上交通流データベース システムの開発”，日本航海学会論文集第 117 号, pp. 19-26, 2007.9.

（17）長谷川和彦・角田泰涁：AISの運用の実態調査 と受信エラーの分析, 第128回日本航海学会講 演予稿集，1巻1号, pp. 47-59，2013.4. 